\section{OAK RIDGE NATIONAL LABORATORY}

maktro maknetra

\section{Advanced Neutron Source Reactor Thermal-Hydraulic Test Loop Facility Description}

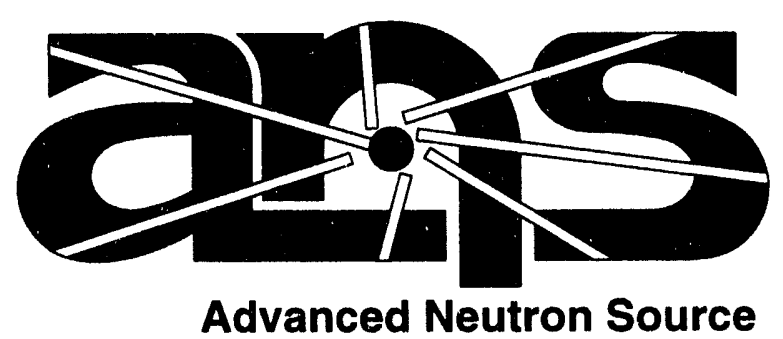

MAMAGED BY

MARTIM MARIETTA ENERGY SYSTEMS, INC.

FOR THE UNITED STATES

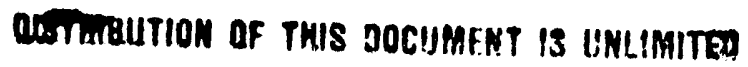

DEPARTMENT OF EMERGY 
This report has been reproduced directly from the best available copy.

Available to DOE and DOE contractors from the Office of Scientific and Technical Information, P.O. Box 62, Oak Ridge, TN 37831; prices available from (615) 576-8401, FTS 626-8401.

Available to the public from the National Technical Information Service, U.S. Department of Commerce, 5285 Port Royal Rd., Springfield, VA 22161.

This report was prepared as an account of work sponsored by an agency of the United States Government. Neither the United States Government nor any agency thereof, nor any of their employees, makes any warranty, express or implied, or assumes any legal liability or responsibility for the accuracy, completeness, or usefulness of any information, apparatus, product, or process disclosed, or represents that its use would not infringe privately owned rights. Reference herein to any specific commercial product, process, or service by trade name, trademark, manufacturer, or otherwise, does not necessarily constitute or imply its endorsement, recommendation, or favoring by the United States Government or any agency thereof. The views and opinions of authors expressed herein do not necessarily state or reflect those of the United States Government or any agency thereof. 
ORNL/TM-12397

\section{ADVANCED NEUTRON SOURCE REACTOR THERMAL-HYDRAULIC TEST LOOP FACILITY DESCRIPTION}
D. K. Felde
R. E. Pawel
G. Farquharson
B. H. Power
J. H. Hardy
A. A. Shourbaji
J. F. King
M. Siman-Tov
M. T. McFee
R. J. Wood
B. H. Montgomery
G. L. Yoder

Date Published-February 1994

Prepared by the

OAK RIDGE NATIONAL LABORATORY

Oak Ridge, Tennessee 37831-6285

managed by

MARTIN MARIETTA ENERGY SYSTEMS, INC.

for the

U.S. Department of Energy

under contract No. DE-AC05-84UR21400 


\section{TABLE OF CONTENTS}

LIST OF FIGURES $\ldots \ldots \ldots \ldots \ldots \ldots \ldots$

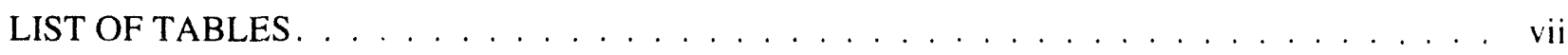

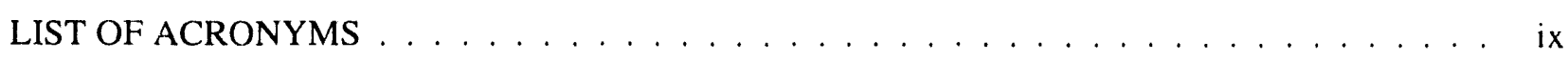

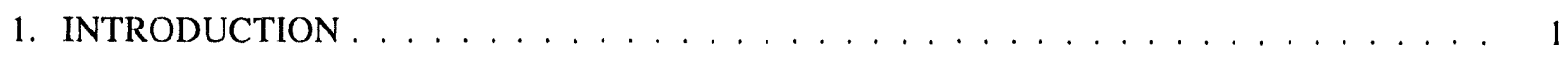

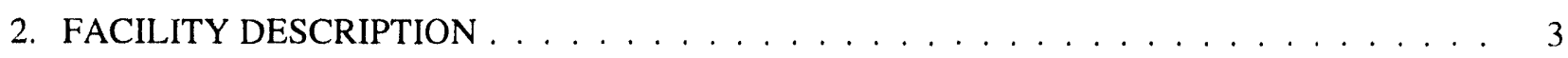

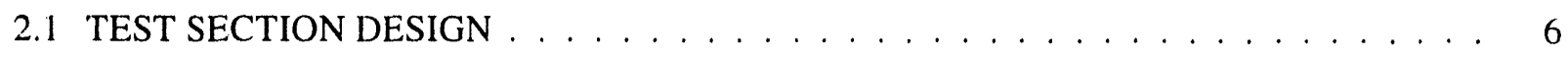

2.2 PREINSTALLATION OF THE TEST SECTION $\ldots \ldots \ldots \ldots \ldots$

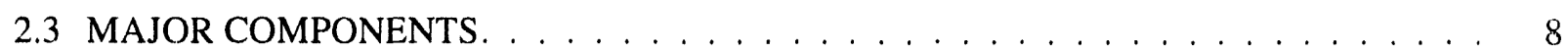

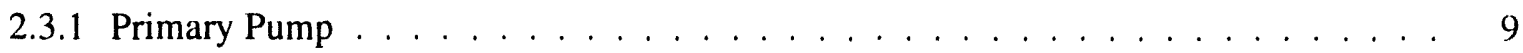

2.3 .2 Heat Exchangers . . . . . . . . . . . . . . . . . . . . . . . . . 9

2.3 .3 Power Supplies. . . . . . . . . . . . . . . . . . . . . . . . . . 10

2.3 .4 Low-Pressure System . . . . . . . . . . . . . . . . . . . . . . . . . . 11

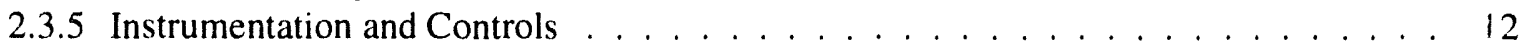

2.3.5.1 Temperature. . . . . . . . . . . . . . . . . 12

2.3.5.2 Flow. . . . . . . . . . . . . . . . . . . . 13

2.3.5.3 Pressure and Differential Pressure . . . . . . . . . . . . . . . . . . . 16

2.3.5.4 Power-Voltage and Current . . . . . . . . . . . . . . . . . . . 16

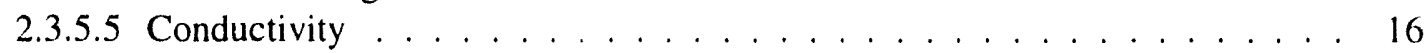

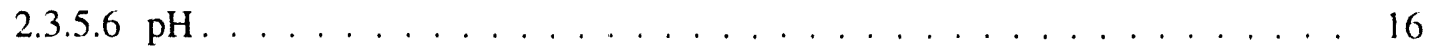

2.3.5.7 Programmable Logic Control (PLC) . . . . . . . . . . . . . . . . . . . . 16

Start-up Sequence . . . . . . . . . . . . . . . . . . . . . . . 17

Shutdown Interlocks . . . . . . . . . . . . . . . . . . . . . . . . . . . 17

2.3.5.8 Process Controls . . . . . . . . . . . . . . . . . . . . . . 17

2.3.5.9 Data Acquisition . . . . . . . . . . . . . . . . 18

3. EXPERIMENTAL PROCEDURES . . . . . . . . . . . . . . . . . . . . . . . . . . . . . . . 19

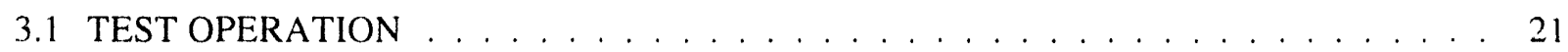

3.1 .1 Flow Excursion Tests Without Burnout . . . . . . . . . . . . . . . . . . . 21

3.1 .2 Flow Excursion Tests With Burnout . . . . . . . . . . . . . . . . . . . . 21

3.1 .3 Critical Heat Flux $(\mathrm{CHF})$ T'ests. . . . . . . . . . . . . . . . . . . . 22

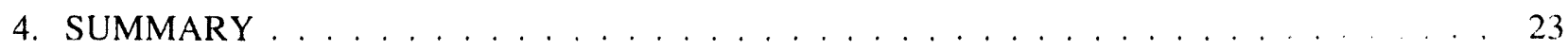

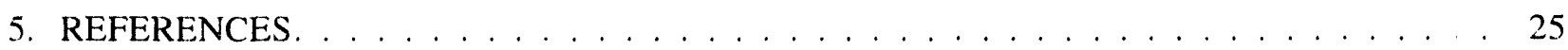




\section{LIST OF FIGURES}

2.1 Thermal-Hydraulic Test Loop, isometric view . . . . . . . . . . . . . . . 3

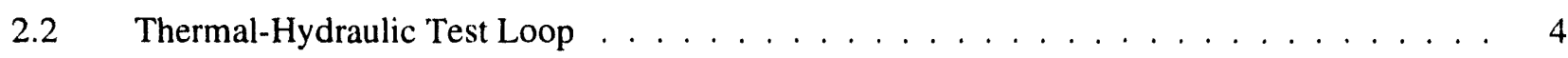

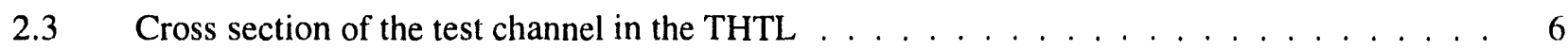

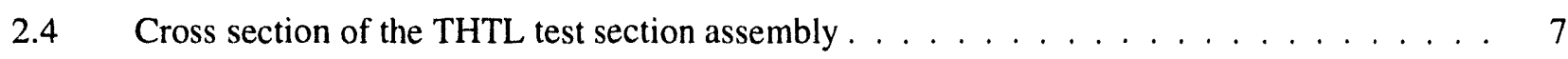

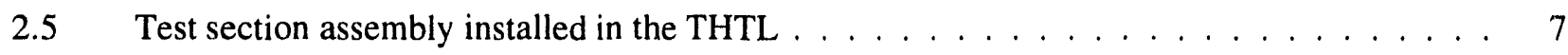

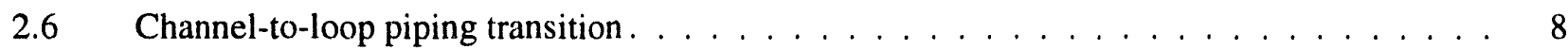

2.7 Operating region for THTL primary pump $(750 \mathrm{rpm}$ maximum speed $) \ldots \ldots$

2.8 Schematic diagram of the low-pressure (water chemistry) system . . . . . . . . . . . 12

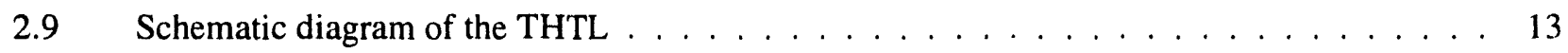

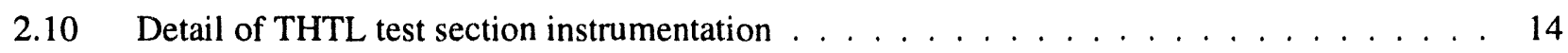

3.1 Pressure drop vs flow rate relationship for various boundary conditions . . . . . . . . . 20 


\section{LIST OF TABLES}

2.1 Thermal-Hydraulic Test Loop operating parameters $\ldots \ldots \ldots \ldots$

2.2 THTL primary heat exchanger specifications $\ldots \ldots \ldots \ldots \ldots \ldots$

2.3 Power supply specifications for THTL $\ldots \ldots \ldots \ldots \ldots \ldots \ldots$

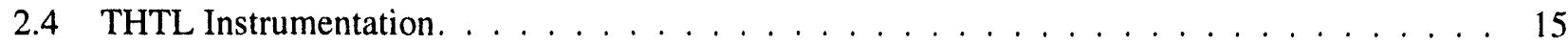

2.5 Data-acquisition system specifications $\ldots \ldots \ldots \ldots \ldots \ldots$ 


\section{LIST OF ACRONYMS}

\begin{tabular}{|c|c|}
\hline ANSR & Advanced Neutron Source Reactor \\
\hline $\mathrm{CHF}$ & critical heat flux \\
\hline DNB & departure from nucleate boiling \\
\hline $\mathrm{FE}$ & flow excursion \\
\hline IB & incipient boiling \\
\hline LOCA & loss of coolant accident \\
\hline NPDM & ethylene propylene diene monomer \\
\hline OFI & onset of flow instability \\
\hline ONVG & onset of net vapor generation \\
\hline OSV & onset of significant void \\
\hline PID & proportional-integral-derivative \\
\hline PLC & programmable logic control \\
\hline RTD & resistance temperature device \\
\hline SCR & silicon-controlled rectifier \\
\hline THTL & Thermal-Hydraulic Test Loop \\
\hline TIG & tungsten-inert gas (welding) \\
\hline TTL & transistor-transistor logic \\
\hline
\end{tabular}




\title{
ADVANCED NEUTRON SOURCE REACTOR THERMAL-HYDRAULIC TEST LOOP FACILITY DESCRIPTION
}

\author{
D. K. Felde et al.
}

\section{INTRODUCTION}

The Thermal-Hydraulic Test Loop (THTL) is a facility for experiments constructed to support the development of the Advanced Neutron Source Reactor (ANSR) at Oak Ridge National Laboratory. The ANSR is both cooled and moderated by heavy water and uses uranium silicide fuel. The core is composed of two coaxial fuel-element annuli, each of different diameter. There are 684 parallel aluminum-clad fuel plates ( 252 in the inner-lower core and 432 in the outer-upper core) arranged in an involute geometry that effectively creates an array of thin rectangular flow channels. Both the fuel plates and the coolant channels are $1.27 \mathrm{~mm}$ thick, with a span of $87 \mathrm{~mm}$ (lower core), $70 \mathrm{~mm}$ (upper core), and $507-\mathrm{mm}$ heated length. The coolant flows vertically upwards at a mass flux of $27 \mathrm{Mg} / \mathrm{m}^{2} \mathrm{~s}$ (inlet velocity of $25 \mathrm{~m} / \mathrm{s}$ ) with an inlet temperature of $45^{\circ} \mathrm{C}$ and inlet pressure of $3.2 \mathrm{MPa}$. The average and peak heat fluxes are approximately 6 and $12 \mathrm{MW} / \mathrm{m}^{2}$, respectively.

The availability of experimental data for both flow excursion (FE) and true critical heat flux (CHF) at the conditions applicable to the ANSR is very limited. The THTL was designed and built to simulate a full-length coolant subchannel of the core, allowing experimental determination of thermal limits under the expected ANSR thermal-hydraulic conditions.

For these experimental studies, the involute-shaped fuel plates of the ANSR core with the narrow $1.27-\mathrm{mm}$ flow gap are represented by a narrow rectangular channel. Tests in the THTL will provide both single- and two-phase thermal-hydraulic information. The specific phenomena that are to be examined are (1) single-phase heat-transfer coefficients and friction factors, (2) the point of incipient boiling, (3) nucleate boiling heat-transfer coefficients, (4) two-phase pressure-drop characteristics in the nucleate boiling regime, (5) flow instability limits, and (6) CHF limits.

Although the facility's primary aim is to develop the thermal-hydraulic correlations at the ANSR nominal conditions for normal operation and safety margin analysis, tests will also be conducted that are representative of decay heat levels at both high pressure (e.g., loss of off-site power) and low pressure [e.g., a loss of coolant accident (LOCA)] as well as other quasi-equilibrium conditions encountered during transient scenarios. Additional series of tests will examine the effects of oxide on the thermal limits as well as substituting $\mathrm{D}_{2} \mathrm{O}$ for $\mathrm{H}_{2} \mathrm{O}$ as the coolant to confirm the thermal limit behavior with heavy water.

This report provides a description of the test facility, the test channel, and associated measurement systems. In addition, the experimental approach used for thermal limit testing is described. 


\section{FACILITY DESCRIPTION}

An isometric view of the facility is shown in Fig. 2.1. The loop is composed of two primary subsystems: a high-pressure system, which includes the test section, and a low-pressure system, used for monitoring and controlling water chemistry. Wetted materials in both subsystems are 300 series stainless steel (304 and 316), with the exception of the pump stator, which is ethylene propylene diene monomer (EPDM), and the pump rotor, which is 17-4 stainless steel. The loop has a rated design pressure of $6.9 \mathrm{MPa}$. Operating pressure is effectively limited to $5.5 \mathrm{MPa}$ by an internal bypass on the pressurizing pump that provides system makeup water. Nominal operation for ANS testing will be at 3.2-MPa test section inlet pressure.

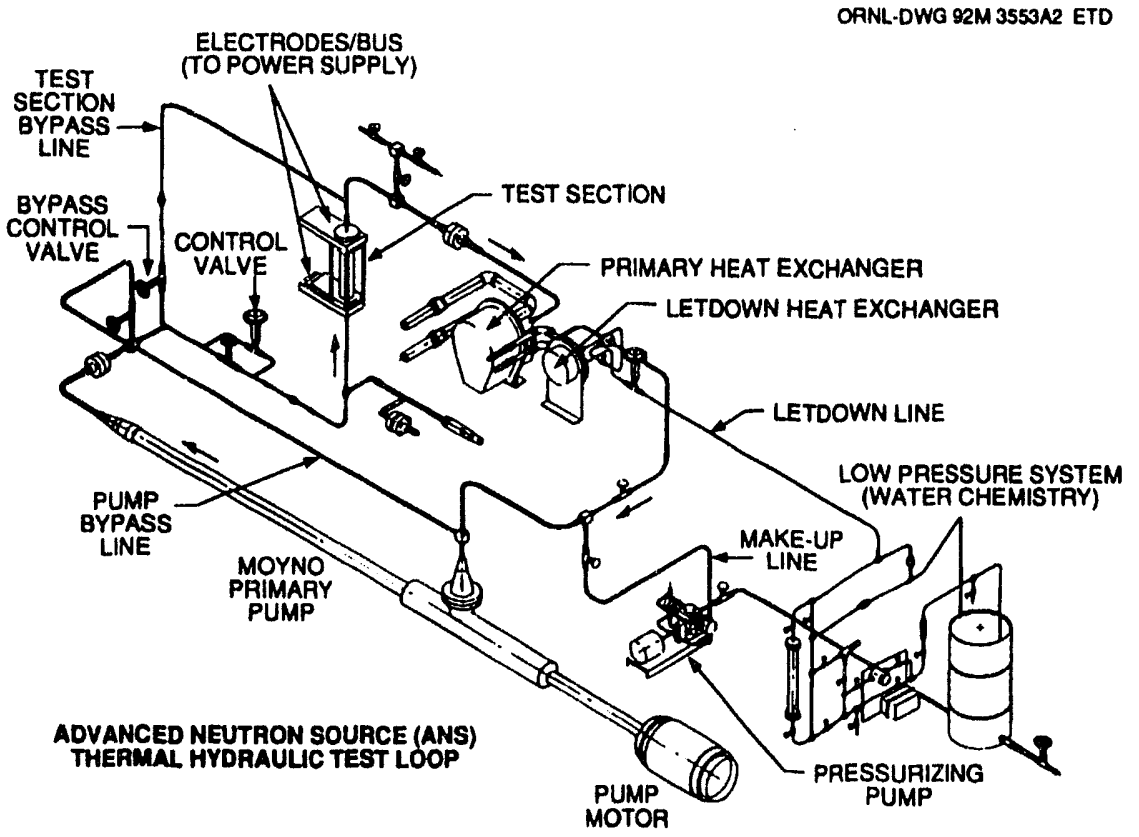

Fig. 2.1. Thermal-Hydraulic Test Loop, isometric view.

In the high-pressure system, water flows from the pump discharge through the primary line to the test section or through a bypass line around the test section. This flow split is controlled by a flow control valve on the test section line in conjunction with a manual valve on the test section bypass line. Flow in both lines is measured by turbine flowmeters. Pressure and temperature of the water are measured at the test section inlet and outlet as well as at the pump suction. An additional pressure measurement is made just upstream of the test section flow control valve to allow calculation of pressure drop in the test section flow leg. A heat exchanger downstream of the test section provides the heat sink for the system. The heat exchanger is designed to remove up to $410 \mathrm{~kW}$. Inlet water temperature to the test section is controlled by varying the secondary flow to the heat exchanger. The primary flow leaving the main heat exchanger returns to the suction of the Moyno pump. A bypass line, downstream of the pump discharge but upstream of the test section/test section bypass flow split, is also available to direct flow back to the pump suction directly.

A pressure control valve on the letdown line downstream of the primary heat exchanger is used in conjunction with a pressurizing pump to control system pressure. The pressurizing pump provides makeup flow to the high-pressure system at a constant flow rate determined by its speed setting. Because the 
letdown pressure control valve automatically adjusts to maintain measured system pressure at the operatorselected set point, the speed setting on the pressurizing pump ultimately controls the letdown flow rate for the loop. A letdown heat exchanger is located upstream of the letdown pressure control valve to prevent flashing on the downstream side of the control valve. The letdown flow is routed to the low-pressure system, where water quality is monitored. Conductivity and $\mathrm{pH}$ are measured prior to sending the water through an ion-exchange column to remove impurities. The letdown flow is then discharged into the sump tank. Tive sump tank provides the suction source for the pressurizing pump, which discharges into the high-pressure system on the suction side of the Moyno pump. Control of water $\mathrm{pH}$ can also be maintained for the system by adding acid to the sump tank if desired.

Two dc power supplies provide direct electrical-resistance heating of the test section. These $12-\mathrm{V}$ power supplies are rated at 16,000 A and 25,000 A and are bussed in parallel to provide a total rated power of $492 \mathrm{kVA}$. Actual power to the test channel will be limited by the voltage-current characteristics of the test channel itself.

A photograph of the facility is shown in Fig. 2.2. System-rated capacities are summarized in Table 2.1.

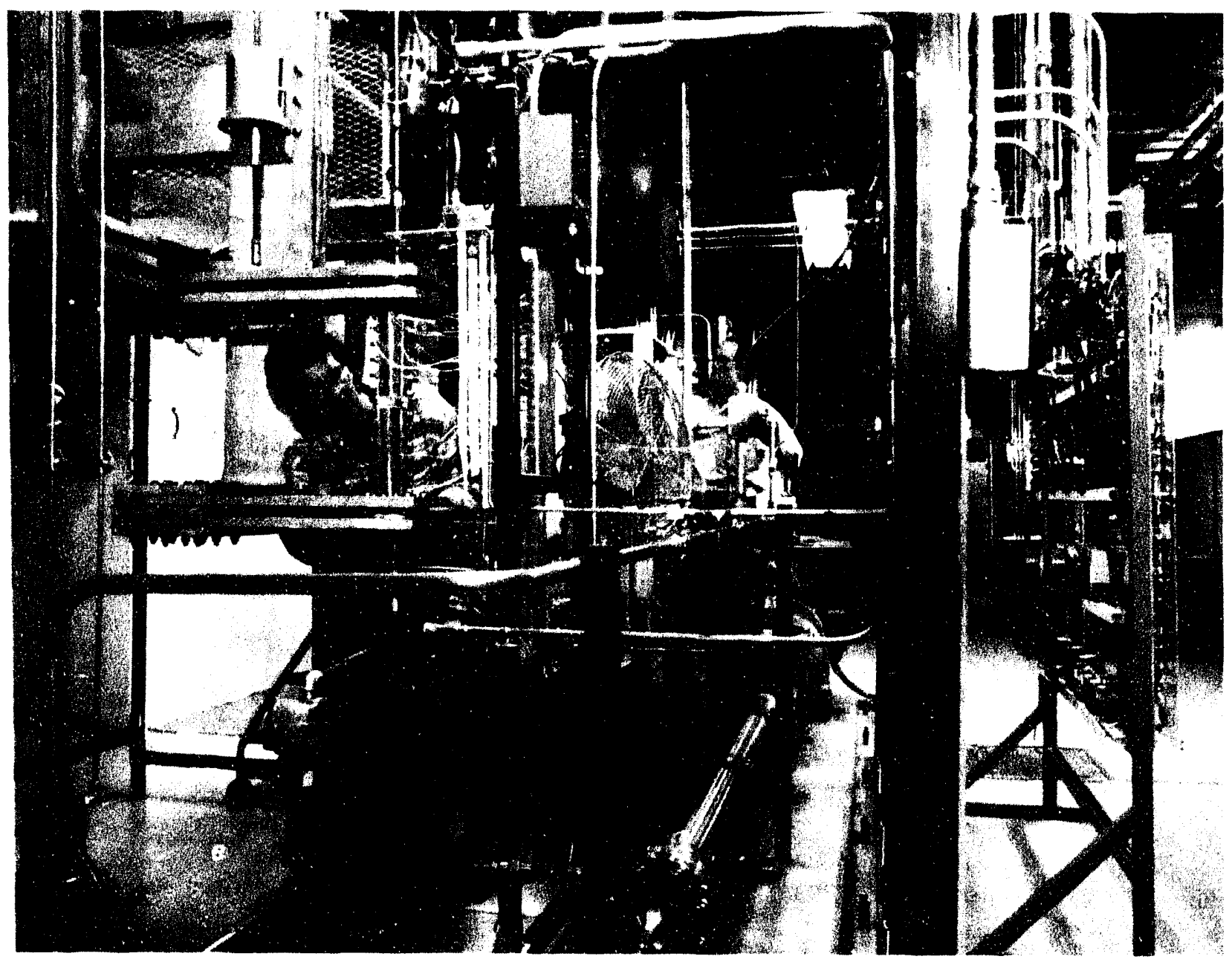

Fig. 2.2. Thermal-Hydraulic Test Loop. 
Table 2.1. Thermal-Hydraulic Test Loop operating parameters

\begin{tabular}{lll}
\hline \multicolumn{1}{c}{ Component } & \multicolumn{1}{c}{ Parameter } \\
\hline Moyno pump & Volumetric flow & $2.5 \mathrm{~L} / \mathrm{s}$ \\
& Differential head & $4.1 \mathrm{MPa}$ \\
Power supplies $^{a}$ & PS-101A & $12 \mathrm{~V} \mathrm{dc}, 25,000 \mathrm{~A}, 300 \mathrm{~kW}$ \\
& PS-101 B & $12 \mathrm{~V} \mathrm{dc}, 16,000 \mathrm{~A}, 192 \mathrm{~kW}$ \\
Heat exchanger & Heat removal capacity & $410 \mathrm{~kW}$ \\
Pressure rating & Loop design pressure & $6.9 \mathrm{MPa}$ \\
& Operating pressure (max) & $6.2 \mathrm{MPa}$ \\
& Pump suction pressure & \\
& Nominal ANS inlet pressure & $5.5 \mathrm{MPa}$ \\
Loop bulk temperature & Nominal ANS inlet temperaiure & $3.2 \mathrm{MPa}$ \\
& Pump temperature limit & $45^{\circ} \mathrm{C}$ \\
\hline
\end{tabular}

${ }^{a}$ Power supply systems are bussed in parallel.

${ }^{b}$ Pump suction pressure is limited by an internal by pass in the system pressurizing pump.

Instrumentation and control systems are designed to provide data for analysis of thermal-hydraulic conditions in the test channel as well as for system control input.

The test section and boundary conditions to the test section are of primary interest for thermalhydraulic limit determination. Inlet and outlet water temperatures are measured by platinum resistanc: temperature devices (RTDs). Inlet pressure and differential pressure across the test section are measured by transmitters for process control and steady-state measurements. Redundant measurements are made using fast-response transducer-type instruments that input into a separate "fast" data-acquisition system. Test section volumetric flow and bypass volumetric flow are measured using turbine flowmeters. These instruments provide input into the standard data-acquisition system and into the fast data-acquisition system.

Measurements are also made on loop process parameters for control purposes. These measurements include pump suction pressure and temperature and electrical bus temperature at several locations. The low-pressure system is instrumented to measure water quality in the letdown flow. Temperature is measured downstream of the pressure control valve. Conductivity and $\mathrm{pH}$ of this letdown stream are measured before the water flows through the ion-exchange column. Sampling ports are available for offline measurements.

A programmable logic control (PLC) system is used for system control and protection. The logic is designed to ensure correct operating sequences for system components and to provide operating limits for parameters such as pressure, flow, and test channel power. The system is designed to provide removal of power to the test section and subsequent shutdown of the loop upon detection of conditions that may affect loop integrity.

An integrated six-channel controller is used to maintain test section inlet temperature, test section velocity, test section power, and loop pressure. The six-channel controller has the capability for providing programmable set points for all six channels simultaneously.

The test section design, major facility components, and the instrumentation and controls system are described in more detail in the following sections. 


\subsection{TEST SECTION DESIGN}

The cross section of the aluminum test channel design is shown in Fig. 2.3. The cross-sectional design is similar to that used by Gambill and Bundy. 'The channel has the ANS prototypic $1.27 \mathrm{~mm}$ flow channel gap with a reduced channel width $(12.7 \mathrm{~mm}$ vs the ANSR 87 - and $70-\mathrm{mm}$ fuel plate widths) in order to limit total power requirements to the test section. Channel wall thickness is determined by the necessity to match the voltage/current characteristics of the test channel to the power supplies. The reduced wall thickness at the radiused ends is designed to prevent heat flux peaking on the ends of the channel. The ratio of heat flux on the radiused ends to that on the flats for the design shown is $36 \%$. The .est channel is enclosed inside a stainless steel pressure backing and is isolated thermally and electrically from this backing by Mycalex insulation. The cross section of the test section assembly is shown in Fig. 2.4. The test channel is welded into flanges on each end to provide electrical and loop water interfaces. The outer 25.4-mm periphery of the test section flanges are sandwiched between two 25.4-mm-thick aluminum electrical bus plates. The water connection to the test section is made concentrically inside this bus connection by a $50.8-\mathrm{mm}$ flange and teflon gasket, which are fastened through the test section flange into the ends of the stainless steel backing. The teflon gasket and micarta bolt sleeves provide electrical isolation for the piping loop. The stainless steel backing, which is in direct contact with the test section flanges at both ends, is split in the center and isolated at that point by Mycalex insulation. A photograph of the installed test section assembly is shown in Fig. 2.5. This design effectively separates the electrical-contact requirements from the water-sealing requirements of the loop interface.

The test channel is fabricated from two halves, which are electron-beam welded along the axial length at the radiused edges. The test channel is then welded into aluminum flanges at each end by tungsten-inert gas (TIG) arc welding. The test channel extends through the flanges at each end. Following this welding procedure, the outside flange faces are machined flat and then provided with a 1.6-mm-deep recess to capture the teflon gasket (which provides the loop interface water seal). Measurements of critical dimensions are made throughout the fabrication process, including checks of wall thickness prior to channel fabrication.

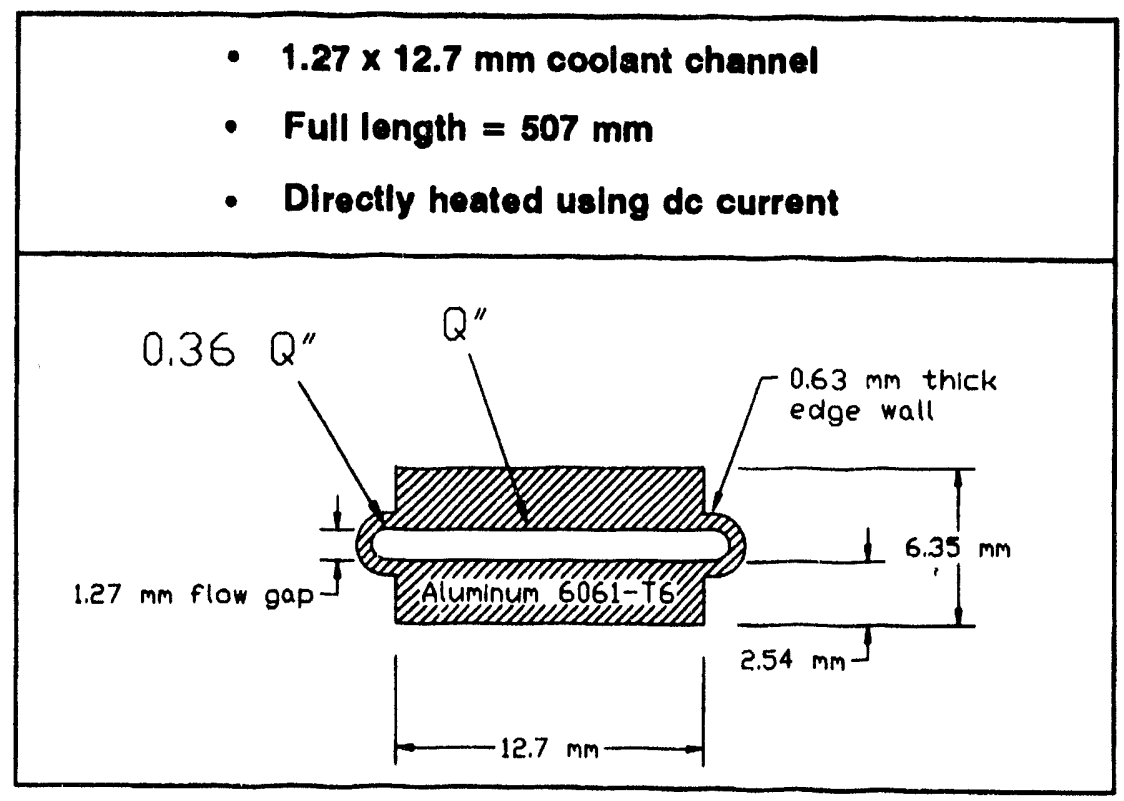

Fig. 2.3. Cross section of the test channel in the THTL. 


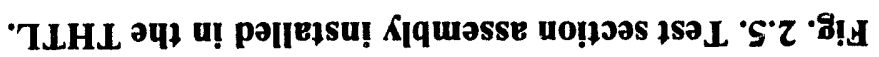

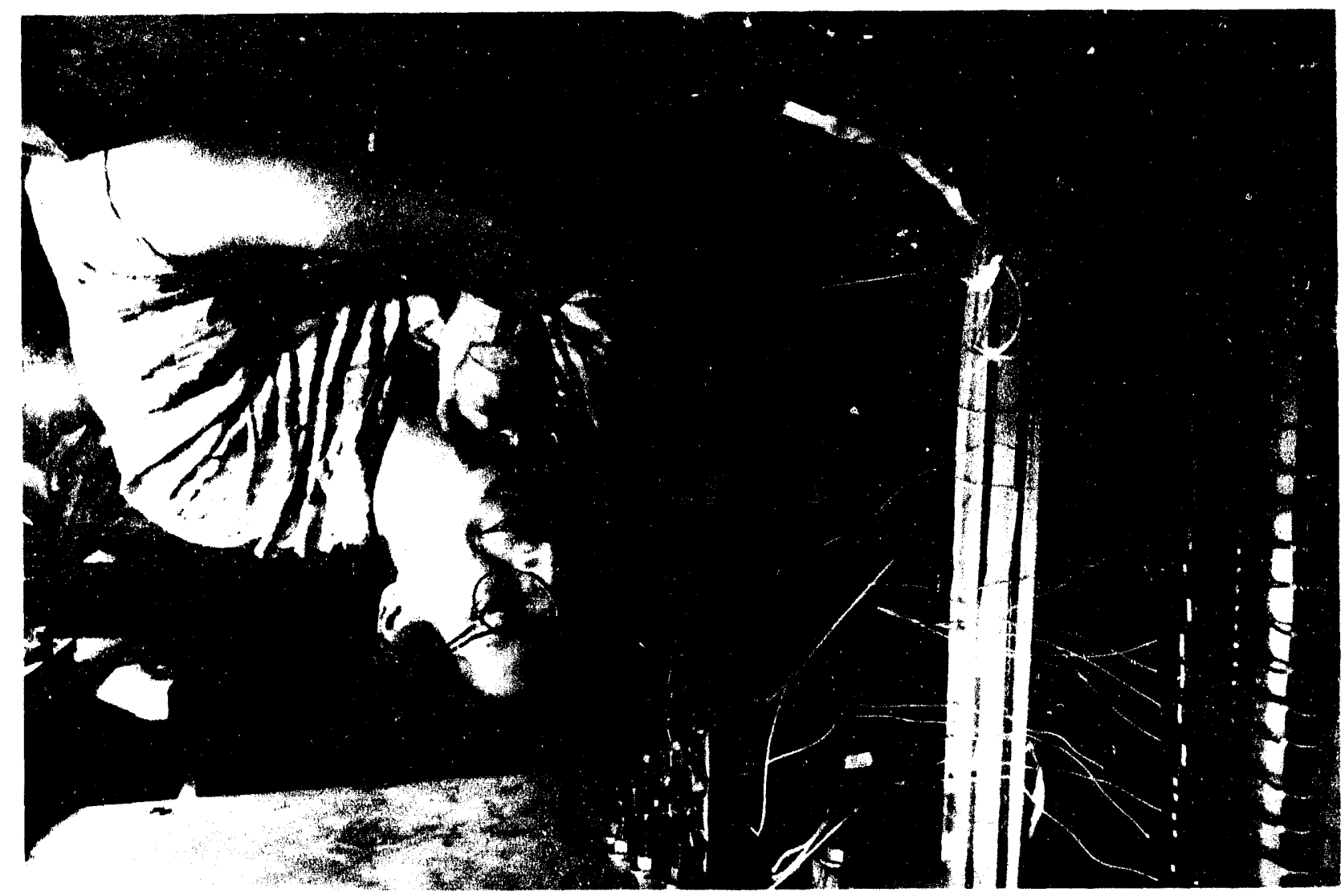

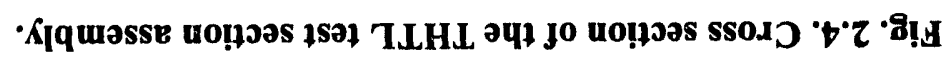

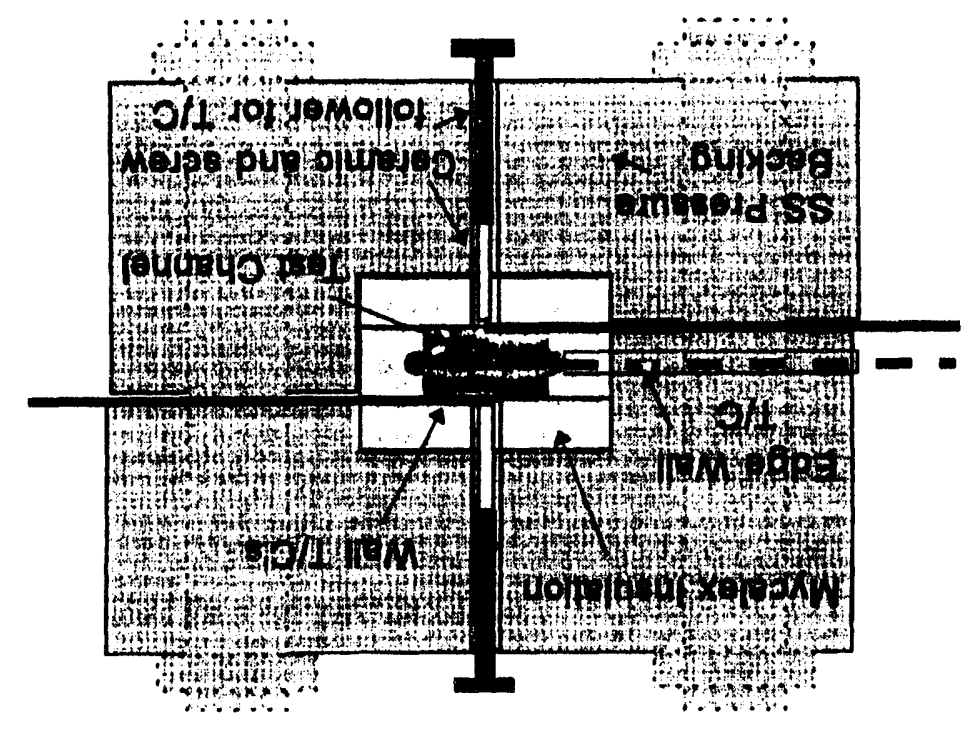


The test channel geometry is maintained through the 25.4-mm-thick end flanges. The interface flange to the loop piping has a machined transition from a rectangular flow channel to the loop tubing. Figure 2.6 shows the approximate dimensions of this transition.

\subsection{PREINSTALLATION OF THE TEST SECTION}

Prior to installation of the test channel assembly into the loop, the channel surface undergoes a surface treatment procedure similar to that used for fuel elements in the High Flux Isotope Reactor and expected to be used for the ANSR fuel elements. This procedure involves cleaning and degreasing followed by an acid treatment and hot water rinse. In addition, the as-fabricated flow channel gap is measured at locations along the axial length using a capacitance-type probe inserted into the channel. These data are used to provide improved conversion of volumetric flow measurements (made upstream of the test section) to local velocities in the channel.

\subsection{MAJOR COMPONENTS}

This section describes major system components in more detail. These include the primary pump, heat exchangers, and power supplies.
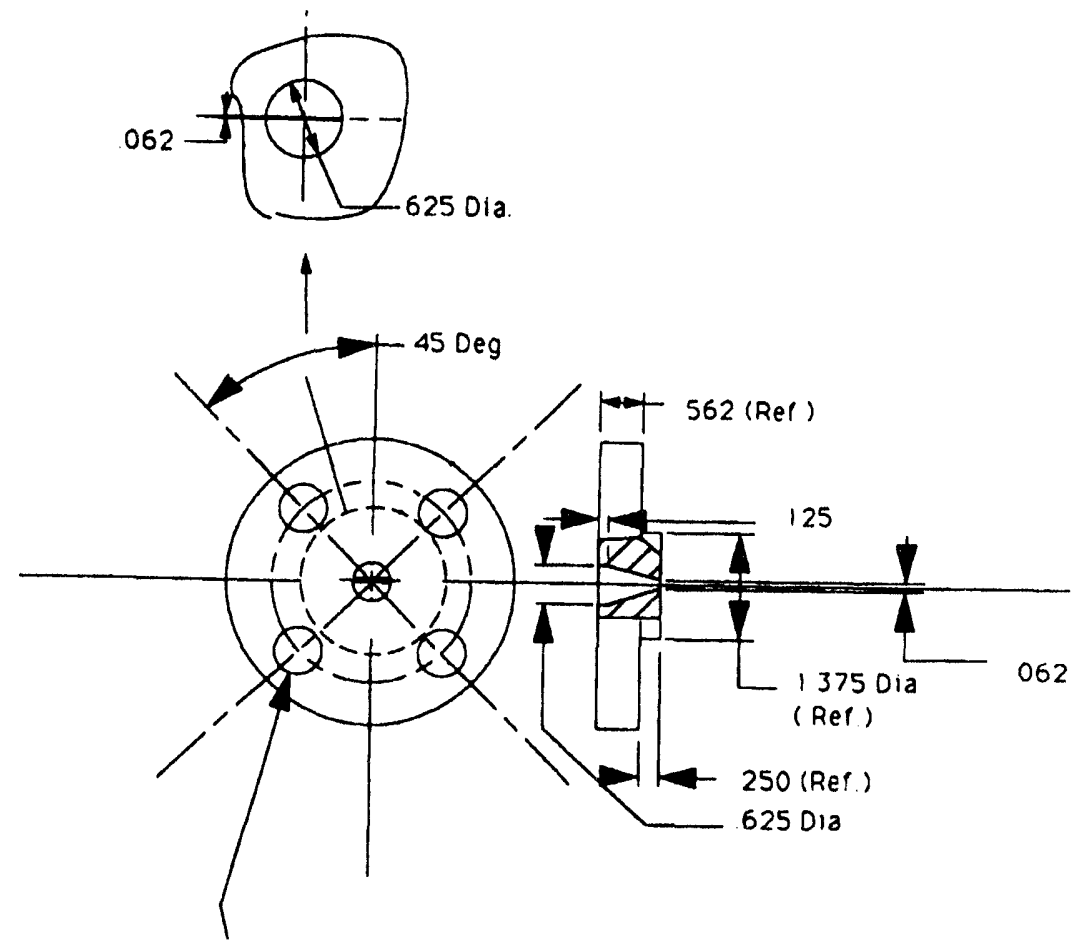

Fig. 2.6. Channel-to-loop piping transition. 


\subsubsection{Primary Pump}

The primary recirculating pump is a Moyno pump driven by a variable-speed motor through a gear drive. ${ }^{2}$ This pump-and-motor combination is capable of providing a wide range of flow and pressure conditions with near-positive displacement characteristics. The pump is a progressing cavity design. The rotor is a single external helix with a round cross section rotating in a double internal helix molded of an abrasion-resistant elastomer bonded within an alloy steel tube. As the rotor turns within the stator, cavities are formed that progress from the suction to the discharge end of the pump. The continuous seal between the rotor and the stator helices keeps the fluid moving steadily at a fixed flow rate proportional to the rotational speed of the pump. A representative set of pump performance curves is shown in Fig. 2.7. Using the variable-speed capability of the motor drive provides capability for operating over most of the flowpressure diagram up to $2.5 \mathrm{~L} / \mathrm{s}(40 \mathrm{gpm})$ flow and $4.1 \mathrm{MPa}(600 \mathrm{psi})$ differential pressure developed across the pump. In combination with the test section bypass line, a very wide range of mass flow conditions (up to $\sim 40 \mathrm{Mg} / \mathrm{m}^{2} \mathrm{~s}$ ) at the test section are possible. These range from a "hard" system with a closed bypass line and near-constant mass flux through the test section to a "soft" system with a fully open bypass line and transient-affected mass flux through the test section.

\subsubsection{Heat Exchangers}

The primary heat exchanger is a Graham Heliflow size $15-20 \mathrm{~S}$. The heat exchanger is a compact shell-and-tube design comprising spiral coils held together between two flat surfaces (the base plate and the end of the casing). The plate and shell confine a closed, spiral-shaped fluid circuit outside the coil, running entirely counterflow to the companion circuit inside the coils (tubes). Design parameters for the primary heat exchanger are shown in Table 2.2.

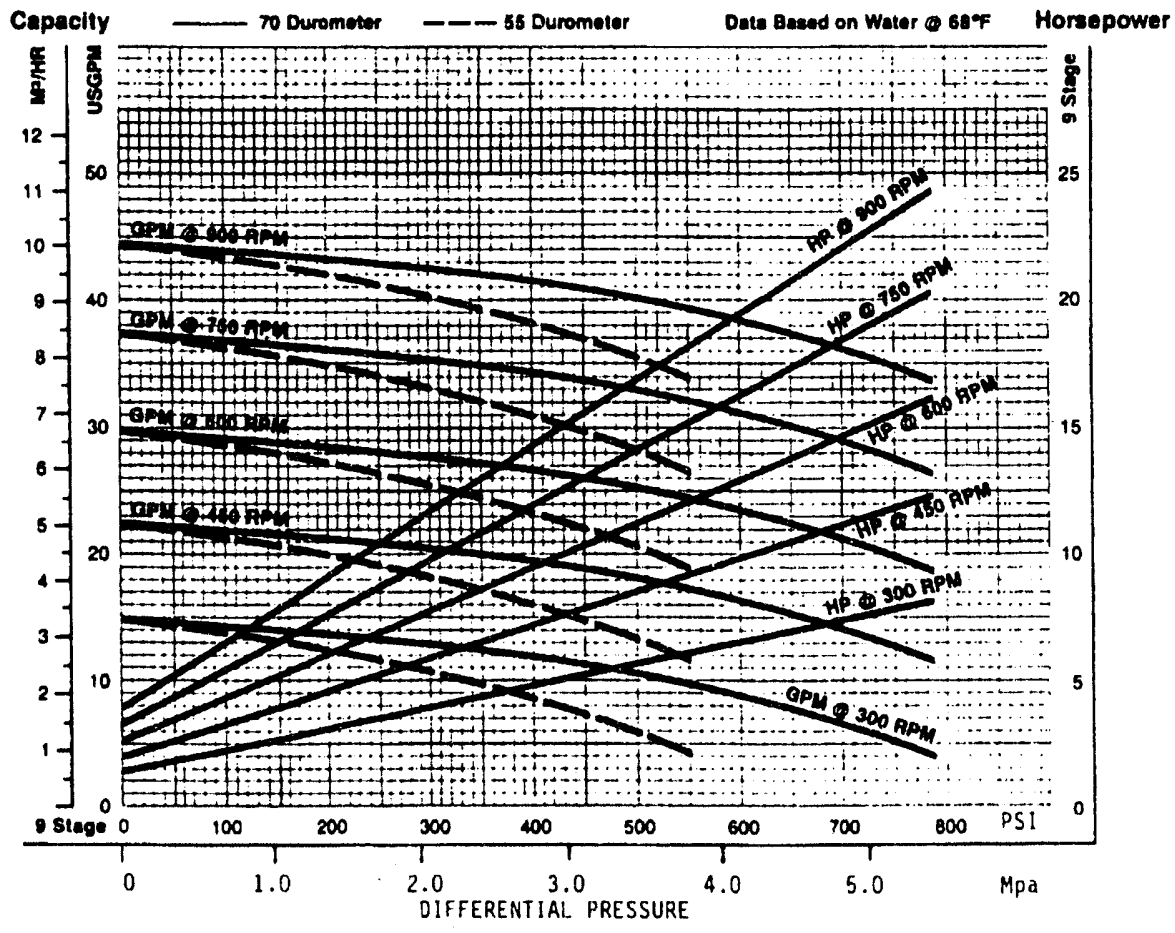

Fig. 2.7. Operating region for THTL primary pump ( $750 \mathrm{rpm}$ maximum speed). 
Table 2.2. THTL primary heat exchanger specifications

Type

Size

Surface area

Tube diameter

Material

Maximum working pressure

Design temperature

Shell side

Material

Maximum working pressure

Design temperature

Nominal capacity ${ }^{a}$
Graham Heliflow

15-20S

$3.0 \mathrm{~m}^{2}$

$12.7 \mathrm{~mm}$

316 SS

$6.9 \mathrm{MPa}$

$315^{\circ} \mathrm{C}$

${ }^{a}$ At nominal primary flow of $0.5 \mathrm{~L} / \mathrm{s}$ and secondary flow of $3.1 \mathrm{~L} / \mathrm{s}$.

A smaller Graham Heliflow heat exchanger is used to cool the letdown flow upstream of the pressure control valve.

Plant process water provides the heat sink for the heat exchangers and cooling for the power supply. This system provides water at approximately $0.5 \mathrm{MPa}$ and $20^{\circ} \mathrm{C}$ in a once-through process. The water is treated by activated-carbon filter tanks for chlorine removal prior to discharge to building storm sewer lines.

\subsubsection{Power Supplies}

The two power supplies convert $480-\mathrm{V}$, three-phase ac power to $12-\mathrm{v}$ dc power at current ratings of $25,000 \mathrm{~A}$ and $16,000 \mathrm{~A}$, respectively.

The primary ac line is connected to wye-delta power transformers by a main contactor. The wye-delta transformers provide power to two well-filtered six-phase rectifier sections (double wye with interphase circuits). These sections are combined by an interphase transformer to provide a twelve-phase system. Voltage and current control is provided by using 24 secondary silicon-controlled rectifiers (SCRs), which are gated in time proportional to the volt ge or current required and are regulated by comparing the resulting output to operator-controlled reference signals. The power supplies are designed to be controlled either manually at the power supply control cabinet or externally (see Sect. 2.3.5.8). In the external mode of operation, the output voltage is regulated by a supplied reference signal. Two modes of regulation are available: a constant current-constant voltage with automatic crossover mode and a constant $d I / d t$ mode. 
The power supply is protected from all of the following conditions: ac under-voltage, ac phase rotation, ac phase loss, internal over-temperature, loss of water flow, open cabinet doors, ac overcurrent, and dc overcurrent. If any of these conditions exists, a power supply fault signal is generated that will drive the power supply into the invert mode of control, which will start to discharge the load and will open the external interlock circuit, which will disengage the main contactor.

The power supplies are of a direct water-cooled design. Most of the power load loss at full load will be removed by water. There are two $0.69-\mathrm{m}^{3} / \mathrm{s}$ blowers to remove the remaining heat. Protection against loss of cooling is provided by a water flow switch and air and water thermal switches.

Power is carried to the test section through a large aluminum plate bus system. The upper electrode interface to the test section includes a section of flexible copper and a spring-loaded support hanger, which allow expansion of the test section when heated. The section of the bus near the test section interface has fans installed for cooling. The remainder of the bus back to the power supplies is cooled only by ambient air.

Table 2.3 includes a summary of operational characteristics of the power supplies. Three additional 16,000 -A power supplies of the same type are available in the facility area but are not currently tied to the THTL.

\subsubsection{Low-Pressure System}

The low-pressure system provides for measurement and control of the loop water chemistry. Letdown flow from the high-pressure system letdown control valve flows through a conductivity measurement cell, a pH measurement sensor and associated flowmeter, a low-pressure system flowmeter, a mixed-bed ionexchange column, and then discharges into the sump tank. The sump tank serves as the suction source for the pressurizing pump, which supplies makeup water to the high-pressure system. This pressurizing pump is driven by a dc motor equipped with a variable-speed controller that ultimately controls the letdown flow

Table 2.3. Power supply specifications for THTL

\begin{tabular}{lll}
\hline & \multicolumn{1}{c}{ Parameter } & \multicolumn{1}{c}{ PS-101A } \\
\hline & Input & \\
Voltage & $480 \mathrm{~V} \mathrm{ac}, 3$ phase & $480 \mathrm{~V}$ ac, 3 phase \\
Current & $570 \mathrm{~A}$ & $340 \mathrm{~A}$ \\
& Output & \\
Voltage & $12 \mathrm{~V} \mathrm{dc}$ & $12 \mathrm{~V} \mathrm{dc}$ \\
Current & $25,000 \mathrm{~A}$ & $16,000 \mathrm{~A}$ \\
Power & $300 \mathrm{kVA}$ & $192 \mathrm{kVA}$ \\
& Cooling water & \\
Maximum pressure & $0.69 \mathrm{MPa}$ & $0.69 \mathrm{MPa}$ \\
Maximum inlet temperature & $32^{\circ} \mathrm{C}$ & $32{ }^{\circ} \mathrm{C}$ \\
Minimum flow rate $\left(14^{\circ} \mathrm{C}\right.$ rise $)$ & $1.9 \mathrm{~L} / \mathrm{s}$ & $0.95 \mathrm{~L} / \mathrm{s}$ \\
\hline
\end{tabular}


rate from the high-pressure system. The system also includes a rupture disc to protect the low-pressure components from high-pressure conditions in the event of failure of the high-pressure system pressure control valve. A schematic diagram of this system is shown in Fig. 2.8 .

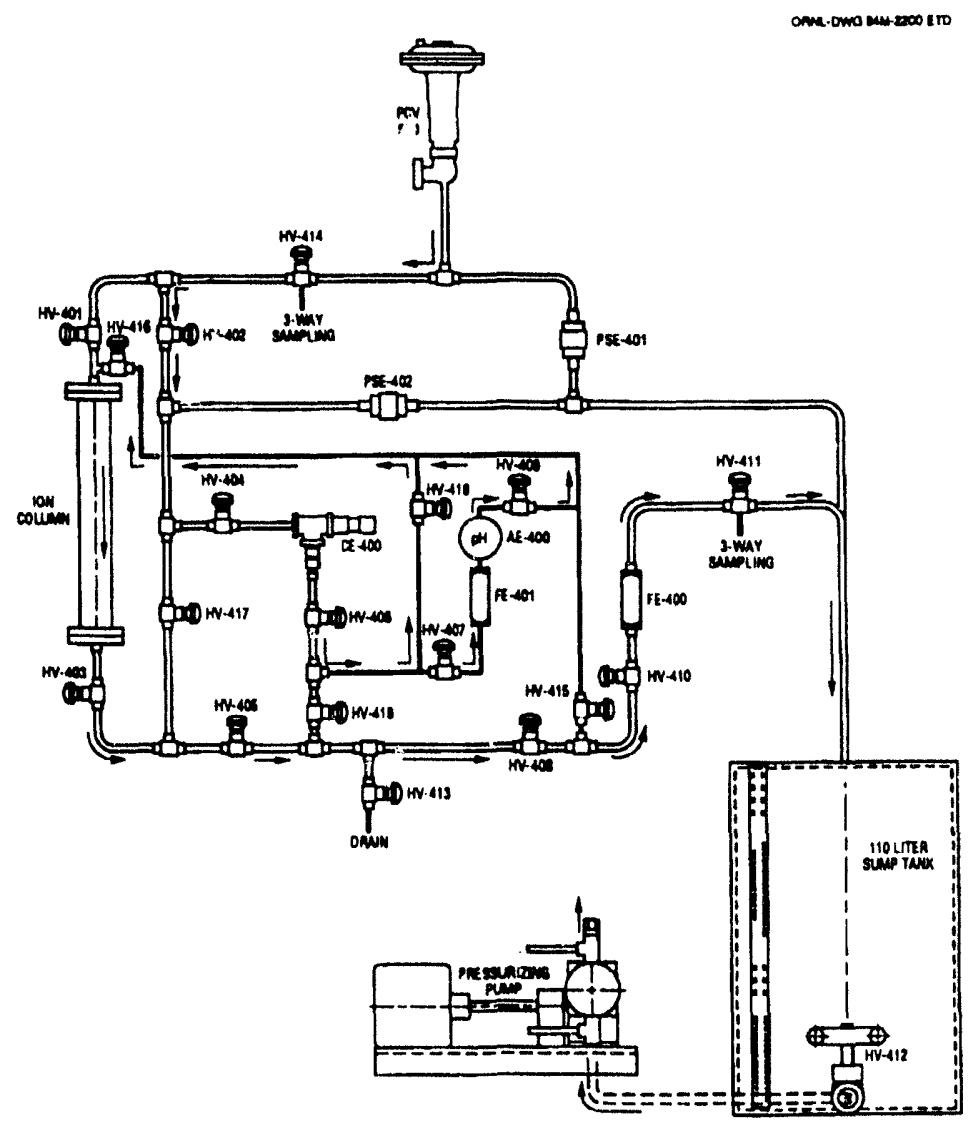

Fig. 2.8. Schematic diagram of the low-pressure (water chemistry) system.

\subsubsection{Instrumentation and Controls}

Instrumentation associated with the loop provides measurements of experimental variables of interest and input for control functions. A simplified schematic of the loop instrumentation is shown in Fig. 2.9. A more detailed view of test section instrumentation is shown in Fig. 2.10. A listing of instruments and measurement ranges is shown in Table 2.4. Primary instruments are described in more detail in the following section.

\subsubsection{Temperature}

Water coolant temperatures are measured at the inlet and outlet of the test section as well as at the pump suction and downstream of the letdown heat exchanger. Platinum RTDs are used for temperatures at the inlet and outlet of the test section, where greater accuracy is desired. In addition, redundant measurement locations are used at the inlet and outlet. The RTDs are stainless steel sheathed probes that are installed via compression-type tee fittings, with the sensor inserted into the center of the flow stream. 


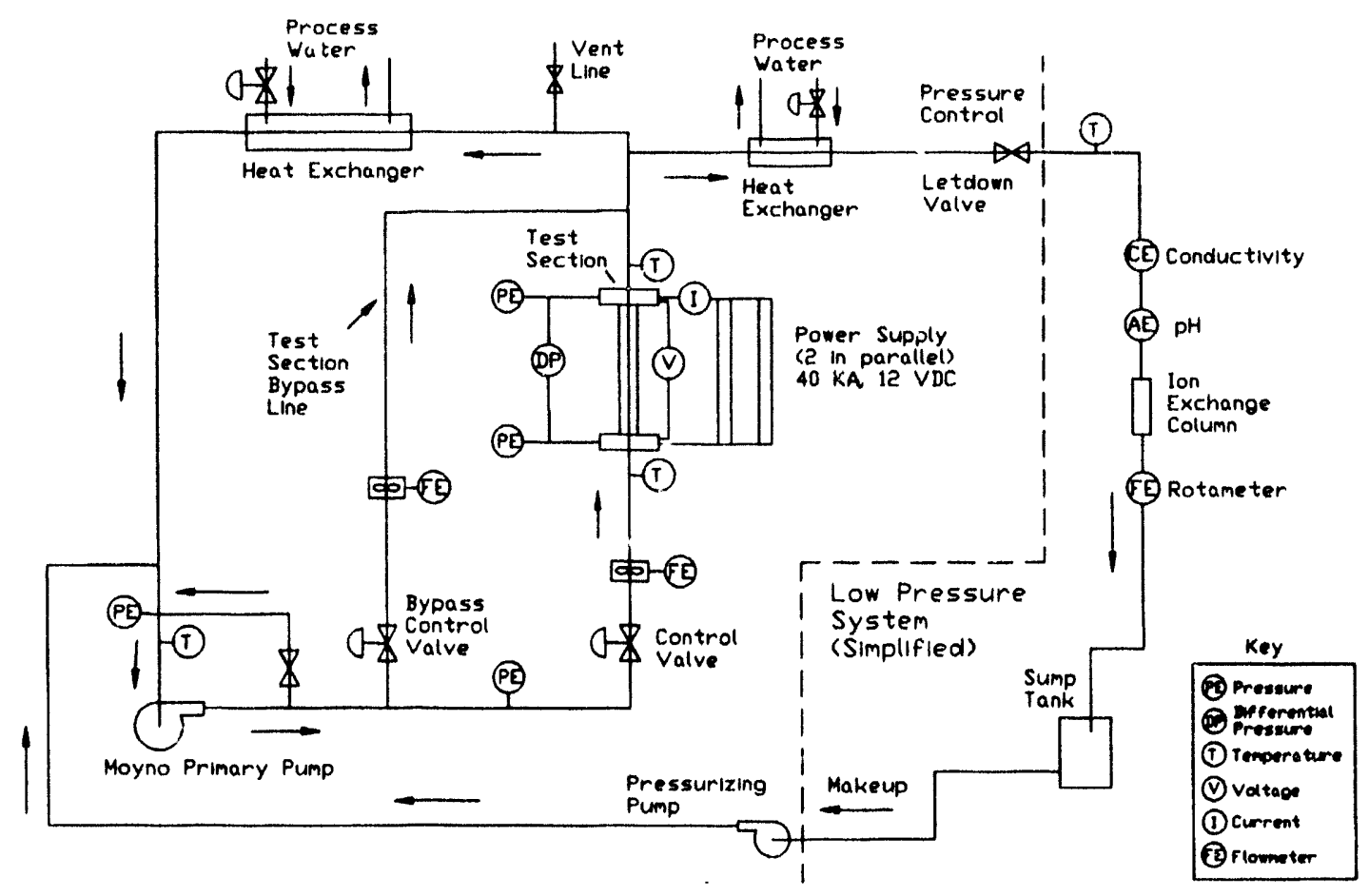

Fig. 2.9. Schematic diagram of the THTL.

These RTDs are located approximately $100 \mathrm{~mm}$ upstream and downstream of the inlet and outlet flanges, respectively (see Fig. 2.10).

Type $\mathrm{K}$ thermocouples are used at the pump suction and downstream of the letdown heat exchanger for bulk coolant measurements. Additional type $K$ thermocouples are installed on the electrical bus at several locations for monitoring purposes. Two methods are used to measure the temperature of the back of the channel wall. Where access permits, a ribbon-type thermocouple manufactured by Nanmac Corporation is spring-loaded against the wall. Where access is not possible, 0.50 - $\mathrm{mm}$-diam thermocouples are inserted between the test channel wall and the ceramic insulator. The junction of the thermocouple is pressed against the wall by a ceramic rod inserted through the SS pressure backing and the ceramic backing. A threaded-screw follower applies pressure on the ceramic rod to force the thermocouple against the wall. Both methods use type $\mathrm{N}$ thermocouples. The locations of these thermocouples are shown in Fig. 2.4. The spacing is staggered as shown to provide improved definition in the region where burnout of the channel is expected. Measurements are made on both sides of the channel for the axial locations shown.

\subsubsection{Flow}

Volumetric flow measurements are made using Hoffer turbine flowmeters in the test section line and the test section bypass line. These instruments are capable of providing both a 4-20 mA output signal and a pulsed output for fast-response measurements $(\sim 5 \mathrm{~ms})$. 


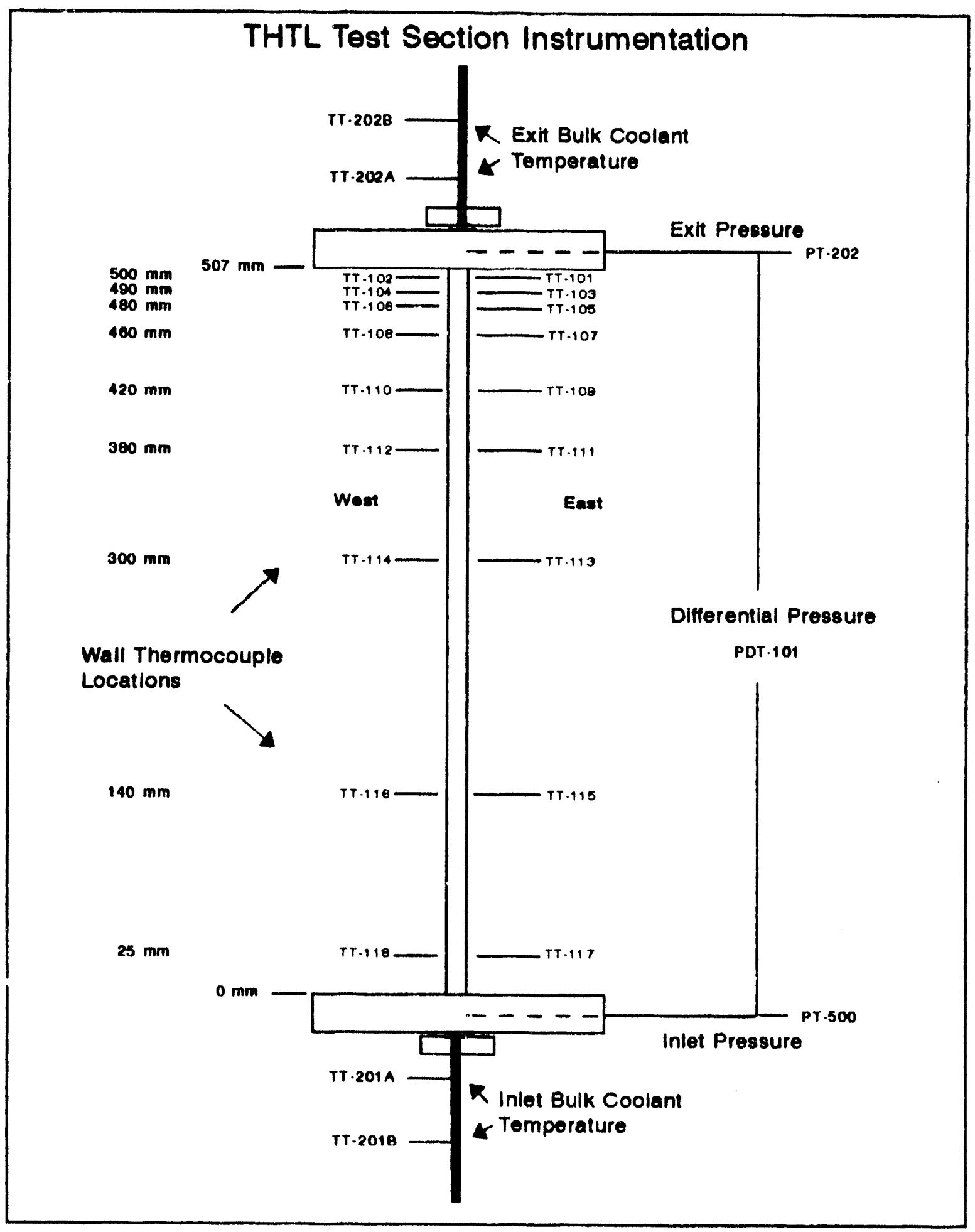

Fig. 2.10. Detail of THTL tesi section instrumentation. 
Table 2.4. THTL Instrumentation

\begin{tabular}{|c|c|c|c|}
\hline IAN & Type & Location & Range \\
\hline TT-101 to TT-118 & Temp (Type N T/C) & Test channel & $0-700^{\circ} \mathrm{C}$ \\
\hline TE-119 & Temp (Type K T/C) & Aluminum bus & $0-200^{\circ} \mathrm{C}$ \\
\hline TE-120 & Temp (Type K T/C) & Aluminum bus & $0-200^{\circ} \mathrm{C}$ \\
\hline TE-121 & Temp (Type K T/C) & Aluminum bus & $0-200^{\circ} \mathrm{C}$ \\
\hline TE-202C & Temp (Type K T/C) & Pump suction & $0-100^{\circ} \mathrm{C}$ \\
\hline TE-500 & Temp (Type K T/C) & Letdown line & $0-100^{\circ} \mathrm{C}$ \\
\hline TT-201A & RTD transmitter & Test section inlet & $0-150^{\circ} \mathrm{C}$ \\
\hline TT-202A & RTD transmitter & Test section exit & $0-300^{\circ} \mathrm{C}$ \\
\hline TE-201B & RTD & Test section inlet & $0-150^{\circ} \mathrm{C}$ \\
\hline TE-202B & RTD & Test section exit & $0-300^{\circ} \mathrm{C}$ \\
\hline PDT-101 & Differential pressure & Test section differential & $0-3.4 \mathrm{MPa}$ \\
\hline PT-200 & Pressure & Pump suction & $0-5.2 \mathrm{MPa}$ \\
\hline PT-202 & Pressure & Test section exit & $0-5.2 \mathrm{MPa}$ \\
\hline PT-203 & Pressure & $\begin{array}{l}\text { Upstream test section control } \\
\text { valve }\end{array}$ & $0-5.2 \mathrm{MPa}$ \\
\hline PT-500 & Pressure & Test section inlet & $0-5.2 \mathrm{MPa}$ \\
\hline FT-201 & Volumetric flow & Test section line & $0-75.7 \mathrm{~L} / \mathrm{s}$ \\
\hline FT-202 & Volumetric flow & Test section bypass line & $0-378.5 \mathrm{~L} / \mathrm{s}$ \\
\hline AT -400 & $\mathrm{pH}$ & Low-pressure system & $0-14$ \\
\hline CT -400 & Conductivity (water) & Low-pressure system & $0-2,000 \mu \mathrm{S} / \mathrm{m}$ \\
\hline JT-101A & Power (one supply) & PS-101A only & $0-300 \mathrm{~kW}$ \\
\hline IE-101A & Current & PS-101A & $0-25,000 \mathrm{~A}$ \\
\hline EE-101A & Voltage & PS-101A & $0-12 \mathrm{~V}$ \\
\hline IE-101B & Current & PS-101B & $0-16,000 \mathrm{~A}$ \\
\hline EE-101B & Voltage & PS-101B & $0-12 \mathrm{~V}$ \\
\hline EE-101 & Voltage & Across test section & $0-12 \mathrm{~V}$ \\
\hline TT -130 & Temp (Type N T/C) & Test section edge & $0-700^{\circ} \mathrm{C}$ \\
\hline TT -131 & Temp (Type N T/C) & Test section edge & $0-700^{\circ} \mathrm{C}$ \\
\hline
\end{tabular}




\subsubsection{Pressure and Differential Pressure}

Pressure is measured at several locations in the loop as shown in the loop instrument schematic (Fig. 2.9). The measurements are made using Rosemount pressure and differential pressure transmitters at all locations. Fast-response transducers, Sensotec model TJE, are used at two redundant locations, the test section inlet and for the test section differential pressure measurement. These have response times of $\sim 1-5 \mathrm{~ms}$.

The test section pressure taps are located in the end flanges. The nominal test channel dimensions extend through the flanges, so the tap is measuring pressure in the channel geometry prior to the transition to the loop tubing. These pressure taps are located (axially) approximately $12.7 \mathrm{~mm}$ from the end of the "heated" length. The locations of these pressure taps are shown in Fig. 2.10.

\subsubsection{Power-Voltage and Current}

Test section power is calculated from measured power supply current and the voltage drop across the test section. The current through the test section is measured via a shunt located in each of the two power supplies. The voltage drop across the test section is measured from taps located on the inlet and outlet flanges of the test section. The $0-12 \mathrm{~V}$ signal is reduced to a $0-8 \mathrm{~V}$ signal using a voltage divider and then input into a Promac Series XZ7 transmitter, which provides isolation and produces a 4-20 mA signal for transmission to the data-acquisition system.

\subsubsection{Conductivity}

A Rosemount model $1181 \mathrm{C}$ conductivity transmitter and associated in-line sensor provide a continuous measurement of conductivity (total dissolved solids) in the letdown flow stream. The transmitter provides an isolated 4-20 mA signal to the data-acquisition system. Reference solutions are used for calibration of the sensor and transmitter.

\subsubsection{6 pH}

A Rosemount model $320 \mathrm{HP}$ high-purity pH sensor is used in conjunction with a model $1181 \mathrm{pH}$ twowire transmitter for making in-line $\mathrm{pH}$ measurements of the system letdown flow. The sensor assembly consists of a stainless steel flow cell with a specially designed liquid junction, temperature compensator, and a weatherproof $A B S$ junction box containing a preamplifier. A rotameter and needle valve are included on the inlet of the flow cell for monitoring and controlling sample flow. The reference electrode is a sealed, double junction type. The measuring electrode is high-impedance glass with a local preamplifier. The model 1181 transmitter provides circuitry for the measurement and transmission of an isolated 4-20 mA signal to the data-acquisition system. Reference buffer solutions are used for calibration of the complete measurement system.

\subsubsection{Programmable Logic Control (PLC)}

A programmable logic control (PLC) system is used to protect equipment and to ensure safe operation of the integrated loop systems. The system is a GE Fanuc Series One PLC, which is capable of handling both analog and digital inputs from process instruments and capable of providing logical control of outputs to system interfaces. The logic incorporated for the loop includes start-up sequences to ensure adequate conditions for component start-up as well as continuous monitoring of process limits within desired 
operating ranges. The logic provides automatic shutdown of the pumps and power supplies when process limits are exceeded.

\section{Start-up Sequence}

Start-up of the primary pump requires that the metering pump is on and that the loop is pressurized above a low-pressure limit set point. Application of power to the test section requires, in turn, that test section volumetric flow exceeds a low-flow-limit set point and that process water is available to the heat exchanger. The power supply controller also has internal flow limit switches that require minimum flow levels to allow closure of the main contactor.

\section{Shutdown Interlocks}

Once power has been applied, process measurements are monitored for operation within a selected range between high- and low-limit set points as appropriate. Limits that will result in system shutdown include low pump-suction pressure, low test-section inlet pressure, high loop pressure, low test-section flow, high outlet bulk-coolant temperature, high test-channel wall temperature, and high bulk-coolant inlet temperature. Actual limit settings are made on indicator switches located on the main control panel and are adjustable to match specific test conditions.

\subsubsection{Process Controls}

A CIMAC 2 controller provides proportional-integral-derivative (PID) automatic feedback control for up to six separate processes. The system currently uses automatic feedback control for system pressure, inlet coolant temperature, test section flow, pump speed, and test section power. In actual practice to date, the automatic control has been used primarily for pressure and inlet temperature control. The other parameters have been operated using the controller in the manual mode. One of the features of this multiloop controller is the capability of providing synchronized programmable multi-loop control of the different processes. This feature provides the capability of introducing transient conditions during a test sequence that would be difficult to control manually, involving test section power, pressure, coolant temperature, and flow.

The controller receives 4-20 mA inputs from process measurement instruments and produces a 4-20 mA output, which is used to drive transducers or to control devices for process control. Each loop may be operated in manual or automatic mode, and the PID parameters are adjustable to match the specific control function. The following are specific functions of the six available control channels:

Channel 1. The test section flow measured by the turbine meter provides the input signal for the flow controller, which can be used to drive the flow control valve on the test section inlet line. For most modes of operation, this control channel is operated in the manual mode with the valve at a specified position.

Channel 2. Test section inlet bulk coolant temperature provides the signal input to the temperature controller. The output of the controller drives a flow control valve positioner on the secondary water flow line to the primary heat exchanger.

Channel 3. Test section exit pressure provides the input signal for pressure control. The output signal from the controller drives the letdown pressure control valve position, which controls letdown flow to the low-pressure system. 
Channel 4. Measurement of the power produced by the 25,000-A power supply provides the input signal for the power control. The controller provides a demand signal back to the power supply.

Channel 5. Spare channel.

Channel 6. This channel is used in the manual mode to provide an external drive signal to the local pump speed controller. Pump speed is controlled by a high-performance pulse-width-modulated inverter that generates a sine-coded, adjustable voltage/frequency three-phase output to the 30-hp pump motor. The inverter can be controlled at its local panel or remotely from the CIMAC 2 controller (which is the normal operating mode).

\subsubsection{Data Acquisition}

A PC-based data-acquisition system is used for recording test data. The system was commercially procured from Dianachart, Inc., and is capable of measuring 48 inputs that are optically isolated and guarded. The system has $16-$ bit resolution over a range of $0.3-\mu \mathrm{V}$ to $10-\mathrm{V}$ input signals and has direct thermocouple and RTD input capability. The system includes menu-driven software and real-time graphing capability. Along with the 48 signal inputs, additional channels are available for generating calculated quantities based on measured channels for display and recording purposes. Some of the system specifications are shown in Table 2.5 .

Table 2.5. Data-acquisition system specifications

\begin{tabular}{ll}
\hline Inputs & Voltage: $0.3 \mu \mathrm{V}$ to $10 \mathrm{~V}$ \\
& Current: $4-20 \mathrm{~mA}, 0-50 \mathrm{~mA}$ \\
& Thermocouple types: JKEBRSTNW \\
& RTDs, strain gages with ranges $-5 \mathrm{~V}$ to $+10 \mathrm{~V}$ \\
& 16 bits $(1 / 65535), 0.3 \mu \mathrm{V}$ minimum \\
Resolution & $\pm 0.02 \%$ \\
Accuracy & 11 on/off, (expandable to 640$), \mathrm{TTL}$ or contact closure \\
Binary inputs & $10 \mathrm{TTL}$ \\
Control outputs & $10,000 \mathrm{M} \Omega / 0.1 \mu \mathrm{F}$ \\
Impedance & $\pm 0.02 \%$ \\
Linearity & $120 \mathrm{~V}, 50 / 60 \mathrm{~Hz}, 0.5 \mathrm{~A}$ \\
Power &
\end{tabular}




\section{EXPERIMENTAL PROCEDURES}

The cooling channels in the ANSR fuel assembly are all parallel and share common inlet and outlet plenums, effectively imposing a common pressure drop across all the channels. This core configuration is subject to FE and/or flow instability that may occur once boiling is initiated in any one of the channels. ${ }^{3,4}$ The FE phenomenon constitutes a thermal limit different from a true CHF or a departure from nucleate boiling (DNB). In such a system, initiation of boiling in one of the channels (i.e., the hot channel) can result in flow redistribution to the other, cooler channels. This process can very rapidly lead to flow starvation, which in turn, leads to a DNB in the hot channel at flows lower than the nominal flow rate. The FE phenomenon is in contrast to a primary DNB that occurs at a nominally constant flow rate, referred to here as a "true CHF."

The more complete way to predict the ocsurrence of FE is to perform flow-vs-pressure-drop analysis of the parallel channels involved and to predict the subsequent flow redistribution under constant and common pressure-drop boundary conditions. Performing this prediction is quite complex because of the uncertainties involved in predicting void fractions and pressure drops in two-phase flow. In reality, after boiling starts, the flow resistance of the channel increases drastically, leading to flow reduction in the channel. The flow reduction promotes more boiling, which rapidly leads to FE. Therefore, it is normally accepted that FE [also referred to as the onset of flow instability (OFI)] will most likely occur near the point where sustained net vapor first appears. This point is called the onset of net vapor generation (ONVG) point ${ }^{5}$ or the point of onset of significant void (OSV).

Maulbetsch and Griffith ${ }^{6}$ and other investigators analytically and experimentally demonstrated the conditions under which excursive instability will occur. They have determined that such instability will occur "if the slope of the (demand) pressure-drop vs flow rate is more negative than that of the external supply system. ${ }^{\text {"T }}$ This statement is expressed mathematically as:

$$
\frac{d\left(\Delta P_{\mathrm{ext}}\right)}{d V}>\frac{d\left(\Delta P_{\mathrm{ts}}\right)}{d V}
$$

Figure 3.1 presents a typical plot of the pressure drop vs flow rate relationship under various boundary conditions. In the case of many parallel channels between large common headers, as is the case in the ANSR, the slope of the external supply system is practically zero and is represented in Fig. 3.1 by horizontal lines (A and B). Based on this observation, FE or OFI conditions were determined in most of the THTL FE experiments by detection of the test section pressure-drop minimum as the flow to the test section was reduced under a constant heat flux. This method allowed for repetition of many nondestructive $\mathrm{FE}$ tests without experiencing an actual $\mathrm{FE}$, which normally causes test section failure. For confirmation and comparison, limited experiments were performed with an actual FE burnout, and some experimentswere run with true CHF burnout under constant flow. To accommodate these experiments, the design of the THTL system had to respond to three separate modes of operation as enumerated below.

1. A "soft" system was used to perform actual FE tests with burnout. In this mode, a large bypass around the test section was fully open so that the flow could split between the test section and the bypass to maintain an almost constant common pressure drop across both, thus closely simulating the ANSR configuration. 


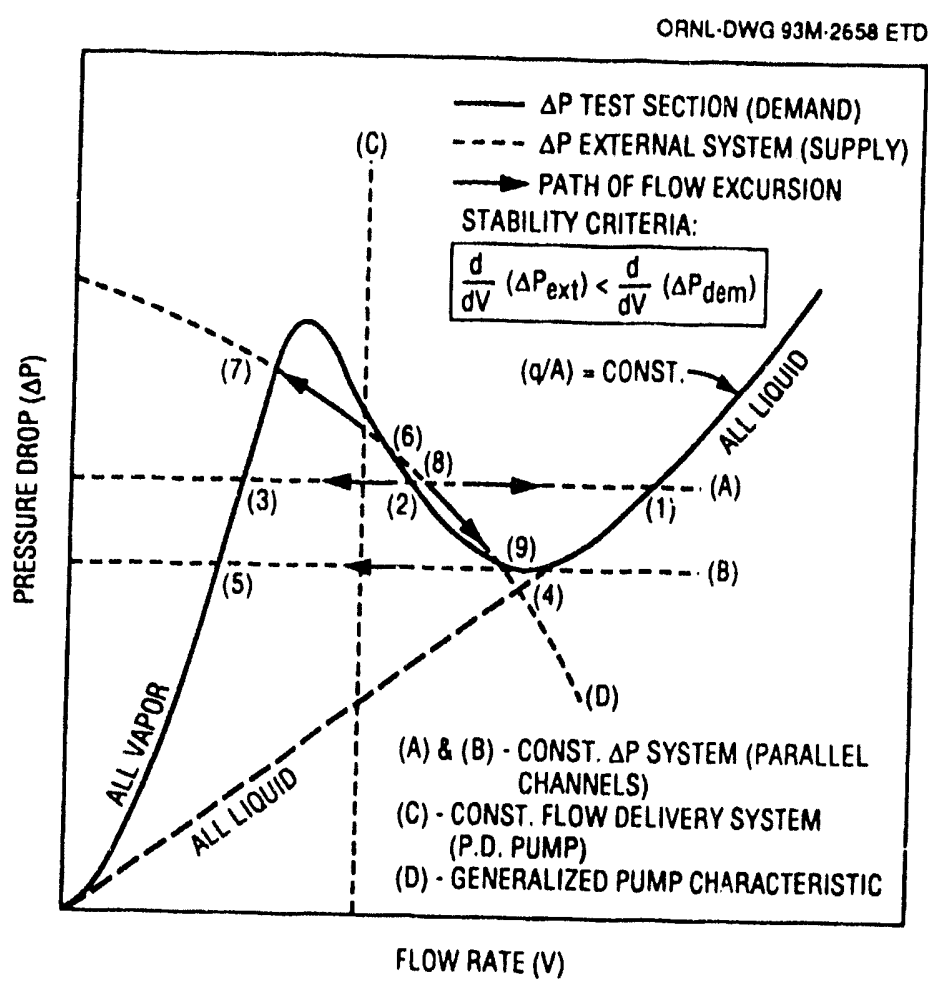

Fig. 3.1. Pressure drop vs flow rate relationship for various boundary conditions.

2. A "stiff" system was used to perform true CHF tests with actual burnout at constant and known flow rates. In this mode, the bypass around the test section was completely closed to maintain a constant flow through the test section. In addition, a near-positive-displacement pump that provides a nearly constant flow rate was used in the primary loop. This pump is insensitive to the system pressure-drop characteristics. Small-diameter piping (to reduce volume) and a throttling valve were also used upstream of the test section inlet to enhance flow stability.

3. A modified "stiff" system was used to perform simulated FE tests without experiencing actual FE. In this mode, a closed or minimal bypass configuration, along with a significant pressure drop across the flow control valve upstream of the test section, was used to prevent actual FE or other flow instability. In this case, the potential for $\mathrm{FE}$ was determined by detecting the minimum pressure drop in a plot of pressure drop vs flow rate (which coincides with the ONVG point) as demonstrated by Maulbetsch and Griffith, ${ }^{6}$ Whittle and Forgan, ${ }^{7}$ Costa, ${ }^{5}$ Johnston, ${ }^{8}$ Dougherty, ${ }^{9}$ and others. Most of the FE tests were performed using this approach.

Because the ANSR has many channels in parallel, an ideal bypass simulation in the THTL would require a very large bypass flow ratio ("infinite bypass") and, therefore, an unrealistically large pump. In practice, however, a reasonable, but not ideal, flow ratio can provide a very close simulation with no significant error. The lowest bypass flow ratio necessary, which still provides sufficiently constant pressure-drop boundary conditions, was investigated in two independent studies-one transient and one steady state. Both studies are based on models simulating the THTL as a pressure-drop vs flow network to determine the sensitivity of the bypass pressure drop to changes in test section flow for a variety of bypassto-test-section flow ratios. The first model showed that bypass ratios $\geq 4$ begin to approach the response of 
an "infinite bypass," with absolute flow rates within $3 \%$ of the infinite bypass steady-state flow rates. ${ }^{10}$ The second model showed in a preliminary way that the slope of the bypass pressure drop with the test section flow rate (supply side $d\left(\Delta P_{\text {ext }}\right) / d V$ in Eq. 1) exceeds the slope of the test section pressure drop vs flow rate curve (demand side $d\left(\Delta P_{t s}\right) / d V$ in Eq. 1) for a bypass ratio of $\geq 3$, satisfying the condition for instability (Eq. 1). This supply-side slope becomes extremely small (practically horizontal) for bypass ratios above $\sim 6$, closely simulating the ANSR parallel channel configuration. (See Fig. 3.1 for the supply and demand pressure-drop relationships.)

\subsection{TEST OPERATION}

\subsubsection{Flow Excursion Tests Without Burnout}

These tests are conducted with additional pressure drops imposed on the test channel flow leg to prevent actual FE leading to channel failure. A closed or minimal bypass flow configuration, along with a significant pressure drop imposed by the position of the test section line flow control valve, is used to prevent actual excursion. The test is initiated by setting test section flow to a level where no boiling will exist at the target heat flux level. The applied power to the test section is then raised to produce the target heat flux level. Exit pressure is automatically controlled via the system letdown valve and high-pressure makeup pump at the desired setting (nominally 1.7 MPa for normal ANS conditions). Process water flow to the secondary side of the heat exchanger is also automatically controlled to maintain the inlet bulk coolant temperature at the desired set point (nominally $45^{\circ} \mathrm{C}$ for normal ANS conditions). Data are recorded continuously during these processes by the PC-based data-acquisition system. Once the system is stabilized and data are obtained under steady-state conditions, the velocity is reduced to a lower level while the measured differential pressure across the test channel is monitored. This reduction is made through either pump speed reduction, flow control valve positioning, bypass flow adjustment, or some combination of these, depending on the proximity of the conditions to the expected minimum. As the minimum is approached, the loop configuration is adjusted to minimize the amount of bypass flow and to maximize the pressure drop across the control valve in order to prevent an actual excursion-to-channel failure. The system is allowed to stabilize at each of the velocity settings selected. Power supply adjustments are made concurrent with velocity changes to maintain the average heat flux constant (because the temperature coefficient of resistivity of the aluminum affects the current-voltage characteristics of the test channel as velocity is reduced and as test-channel wall temperatures increase). Once the minimum in pressure drop has been determined (by observation of increasing pressure drop as velocity is further decieased), the velocity is increased once again, and data are taken at some of the velocity points obtained during the earlier seq:ence for comparison.

\subsubsection{Flow Excursion Tests With Burnout}

These tests are conducted to simulate the bypass that exists because of the large number of channels in the reactor. The loop is configured with the test section control valve and the bypass line directly around this valve in the full open position. The tests are then run in the same manner as described above by setting heat flux, inlet coolant temperature, and exit pressure at the desired values, and reducing test section velocity in steps until failure of the test channel occurs. The test section velocity is controlled by adjusting the test section bypass line manual control valve and pump speed (Fig. 2.1). Ultimate bypass ratios available are limited by the pump capacity. The effect of limited bypass ratio on tests measuring the pointof-flow excursion to actual channel failure is currently being examined both experimentally and analytically. In general, channel failures have occurred at lower velocities than the actual minimum in 
pressure drop vs velocity (where the minimum is the expected point of failure for the "infinite" bypass case).

\subsubsection{Critical Heat Flux (CHF) Tests}

These tests are conducted under nominally constant mass flux conditions in order to measure a true CHF or DNB. The loop is configured with the test section bypass line manual control valve closed so that all of the mass flux delivered by the pump must flow through the test channel. The tests are operated in a manner similar to that described above, with velocity being reduced while holding constant the channel average heat flux, inlet bulk coolant temperature, and exit pressure. 


\section{SUMMARY}

The THTL was constructed to provide experimental measurements of thermal limits and other thermalhydraulic parameters required to support the design and licensing of the ANSR. In the design process, special consideration was given to include the proper pump, test section bypass configuration, and system valving and piping to allow measurement of both $\mathrm{CHF}$ and $\mathrm{FE}$ thermal limits.

The initial focus of the THTL experimentation for the ANSR is the determination of thermal limits under ANS nominal conditions using water as coolant. Plans include additional experiments to be performed with the existing facility and the basic test section design to capture the onset of incipient boiling, single-phase heat transfer coefficients and friction factors, and two-phase heat-transfer and pressure-drop characteristics.

Also included are plans for non-nominal conditions, including low-flow tests simulating shutdown and refueling conditions, low-pressure conditions simulating LOCA and other selective quasi-equilibrium conditions encountered during transient scenarios, the effects of oxide buildup (typical for aluminum), the effects of material and its surface roughness, and the effects of heavy water on the thermal limits (CHF, $\mathrm{FE}$, and incipient boiling). 


\section{REFERENCES}

1. W. R. Gambill and R. D. Bundy, HFIR Heat Transfer Studies of Turbulent Water Flow in Thin Rectangular Channels, ORNL-3079, UC-80-Reactor Technology, Union Carbide Corporation, Oak Ridge Natl. Lab., 1961.

2. Robbins \& Myers Performance Data, Curve 5.10 for 9P6 Moyno Pump, Robbins \& Myers, Inc., Springfield, Ohio, May 15, 1988.

3. M. Leddineg, "Unstabitit der Stromung bei naturlichen und Zwangumlauf," die Warme 61(48), 891-98 (1938).

4. M. Leddineg, "Flow Distribution in Forced-Circulation Boilers," Eng. Digest 10, 85-89 (1949).

5. J. Costa, Measurement of the Momentum Pressure Drop and Study of the Appearance of Vapor and Change in the Void Fraction in Subcooled Boiling at Low Pressure, ORNL/TR-90/21, Martin Marietta Energy Systems, Inc., Oak Ridge Natl. Lab., 1967.

6. J. S. Maulbetsch and P. Griffith, A Study of System-Induced Instabilities in Forced-Convection Flows with Subcooled Boiling, Report No. 5382-35, Massachusetts Institute of Technology, Department of Mechanical Engineering, Cambridge, Massachusetts, April 1965.

7. R. H. Whittle and R. Forgan, "A Correlation for the Minima in the Pressure Drop vs FlowRate Curves for Sub-Cooled Water Flowing in Narrow Heated Channels," Nucl. Eng. \& Design 6, 89-99 (1967).

8. 3. S. Johnston, Subcooled Boiling of Downward Flow in a Vertical Annulus, DPST-88-891, Savannah River Laboratory, 1988.

9. T. Dougherty et al., "Flow Instability in Vertical Down-Flow at High Fluxes," ASME HTDVol. 119, 17-23, Proceedings American Society of Mechanical Engineers (ASME) Winter Annual Meeting, San Francisco, December 1989.

10. D. K. Felde, G. L. Yoder, and D. Skrzycke, "The Advanced Neutron Source Thermal Hydraulic Test Loop," Proceedings 8th Power Plant Dynamics, Control \& Testing Symposium, the University of Tennessee, Department of Nuclear Engineering, Knoxville, May 1992. 


\section{INTERNAL DISTRIBUTION}

1. C. W. Alexander

2. D. J. Alexander

3. R. R. Allen

4. E. E. Alston

5. J. L. Anderson

6. B. R. Appleton

7. J. G. Arterburn

8. R. E. Battle

9. R. S. Booth

10. W. W. Bowman

11. R. A. Brown

12. G. J. Bunick

13-17. J. H. Campbell

18. P. F. Cento

19. N. C. J. Chen

20. K. K. Chipley

21. J. E. Cleaves

22. J. T. Cleveland

23. G. L. Copeland

24. J. R. Dixon

25. F. F. Dyer

26. G. Farquharson

27. K. Farrell

28-33. D. K. Felde

34-40. R. E. Fenstermaker

41. M. L. Gildner

42. H. A. Glovier

43. D. C. Haberkost

44. J. H. Hardy

45. R. M. Harrington

46. J. B. Hayter

47. S. E. Holliman

48. M. M. Houser

49. R. O. Hussung

50. D. T. Ingersoll

51-54. R. L. Johnson

55. J. F. King

56. R. A. Lillie

57. M. A. Linn

58. P. S. Litherland

59. A. T. Lucas

60. J. A. March-Leuba
61. B. S. Maxon

62. G. T. Mays

63. M. T. McFee

64. S. V. McGrath

65. T. J. McManamy

66. G. R. McNutt

67. J. T. Mihalczo

68. R. M. Moon

69. D. G. Morris

70. D. L. Moses

71. R. E. Pawel

72. H. R. Payne

73. F. J. Peretz

74. B. H. Power

75. C. C. Queen

76. S. Raman

77. C. T. Ramsey

78. J. S. Rayside

79. W. R. Reed

80. J. P. Renier

81. J. B. Roberto

82. R. E. Rothrock

83. T. L. Ryan

84. J. P. Schubert

85. D. L. Selby

86. H. B. Shapira

87. A. A. Shourbaji

88. M. Siman-Tov

89. R. P. Taleyarkhan

90. D. W. Theisen

91. P. B. Thompson

92. K. R. Thoms

93. S. R. Tompkins

94. B. D. Warnick

95. M. W. Wendel

96. C. D. West

97. J. L. Westbrook

98. D. M. Williams

99. R. J. Wood

100. B. A. Worley

101. G. T. Yahr

102. G. L. Yoder 
103. ORNL Patent Office

104. Central Research Library

Document Reference Section
105. Y-12 Technical Library

106-107. Laboratory Records

108. Laboratory Records (RC)

\section{EXTERNAL DISTRIBUTION}

109. R. Awan, U.S. Department of Energy, NE-473, Washington, DC 20585

1010. F. Y. Chen, U.S. Department of Energy, Office of Nuclear Safety Performance Assessment, EH-11, CXXI/3, Washington, DC 20585

111. K. K. Conway, Laboratory Facilities Branch, U.S. Department of Energy, Oak Ridge Operations Office, CE-523, P.O. Box 2001, Oak Ridge, TN 37831-2001

112. R. R. Fullwood, Brookhaven National Laboratory, Upton, NY 11973

113. W. R. Gambill, Route 5, Box 220, Clinton, TN 37716

114. A. F. Henry, Professor, Department of Nuclear Engineering, Massachusetts Institute of Technology, 77 Massachusetts Avenue, Cambridge, MA 02139

115. R. A. Hunter, Director, Office of Facilities, Fuel Cycle, and Test Programs, Nuclear Energy Division, U.S. Department of Energy, NE-47, Washington, DC 20585

116. T. L. Kerlin, University of Tennessee, College of Engineering, 315 Pasqua Engineering Building, Knoxville, TN 37996-2300

117. J. A. Lake, Manager, Nuclear Engineering and Reactor Design, Idaho National Engineering Laboratory, P.O. Box 1625, Idaho Falls, ID 83415

118. J. E. Mays, Research and Test Reactor Fuel Elements, Babcock and Wilcox Co., P.O. Box 785, Lynchburg, VA 24505

119. B. H. Montgomery, 109 Miramar Circle, Oak Ridge, TN 37830

120. J. P. Mulkey, U.S. Department of Energy, NE-473, Washington, DC 20585

121. W. T. Oosterhuis, Materials Sciences Division, Office of Basic Energy Sciences, Office of Energy Research, U.S. Department of Energy, ER-132, Washington, DC 20585

122. J. M. Ryskamp, Idaho National Engineering Laboratory, P.O. Box 1625, Idaho Falls, ID 83415-3885

123. J. L. Snelgrove, Coordinator, Engineering Applications, RERTR Program, Argonne National Laboratory, 9700 South Cass Avenue, Argonne, IL 60439

124. I. Thomas, Acting Associate Director, Materials Science Division, Office of Energy Research, U.S. Department of Energy, ER-13, Washington, DC 20585

125-127. U.S. Department of Energy, ANS Project Office, ak Ridge Operations Office, FEDC, MS-821 8, P.O. Box 2009, Oak Ridge, TN 37831-8218

128. H. G. Wood, III, Associate Professor, Department of Mechanical and Aerospace Engineering, Thornton Hall, University of Virginia, Charlottesville, VA 22901

129. Office of Assistant Manager for Energy Research and Development, U.S. Department of Energy, Oak Ridge Field Office, P.O. Box 2001, Oak Ridge, TN 37831-2001

130. Office of Honors and Awards, P. King, P.O. Box 2008, Bldg. 2518, MS-6324, Oak Ridge, TN 37831-6324

131-132. Office of Scientific and Technical Information, P.O. Box 62, Oak Ridge, TN 37831 


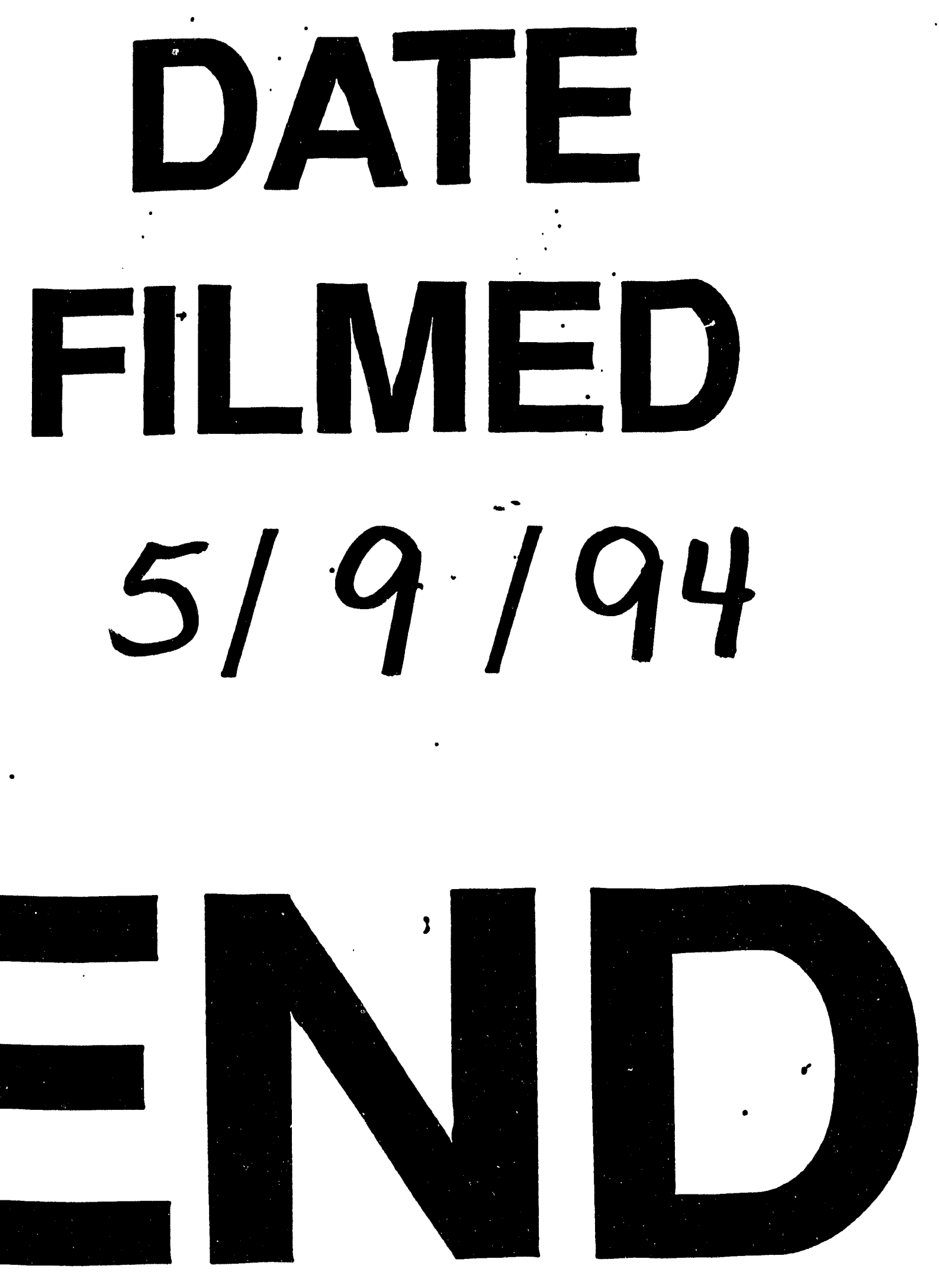


